\title{
Mutasjonstesting ved ikke-småcellet lungekreft
}

\begin{abstract}
Sammendrag
Bakgrunn. Epidermal vekstfaktorreseptor (EGFR) tyrosinkinasehemmere (EGFR-TKI) er en relativt ny klasse legemidler til behandling av ikke-småcellet lungekreft. Den nasjonale faggruppen for lungekreft, Norsk Lunge Cancer Gruppe, anbefaler at pasienter med ikke-småcellet lungekreft testes for mutasjoner i EGFRgenet. Vi rapporterer her erfaringene som er gjort etter at slik testing ble innført i Norge i 2010.
\end{abstract}

Materiale og metode. Opplysninger om hvor mange som er testet, kjønnsfordeling, histopatologiske data og analyseresultater er samlet inn fra de molekylærpatologiske laboratorier ved universitetssykehusene i Tromsø, Trondheim, Bergen og Oslo for perioden mai 2010 til mai 2011.

Resultater. 1058 pasienter med lungekreft ble testet for mutasjoner i EGFRgenet i denne perioden, hvilket svarer til ca. halvdelen av alle som fikk diagnosen ikke-småcellet lungekreft. Mutasjon ble påvist hos 123 pasienter $(11,6 \%)$. Det var en høyere andel mutasjonspositive kvinner enn menn $117,6 \%$ mot $6,3 \%, p<0,001)$, og lavere andel ved plateepitelkarsinom enn ved andre histopatologiske undertyper $13,0 \%$ mot $12,9 \%, p=0,001)$. Av 80 cytologiske prøver var ni $(11,3 \%)$ positive.

Fortolkning. På bakgrunn av den relativt høye mutasjonsfrekvensen og et ikke ubetydelig antall positive i plateepitelkarsinomgruppen, anbefaler vi videreføring av mutasjonstesting av alle pasienter med ikke-småcellet lungekreft.

\section{Odd Terje Brustugun}

otr@ous-hf.no

Åslaug Helland

Avdeling for kreftbehandling

Oslo universitetssykehus, Radiumhospitalet

og

Institutt for klinisk medisin

Universitetet i Oslo

\section{Lars Fjellbirkeland}

Lungeavdelingen

Oslo universitetssykehus, Rikshospitalet

og

Institutt for klinisk medisin

Universitetet i Oslo

\section{Lilach Kleinberg \\ Sarah Ariansen}

Peter Jebsen

Avdeling for patologi

Oslo universitetssykehus

Helge Scott

Avdeling for patologi

Oslo universitetssykehus

og

Institutt for klinisk medisin

Universitetet i Oslo

\section{Tom Dønnem}

\section{Roy Bremnes}

Kreftavdelingen

Universitetssykehuset Nord-Norge

og

Institutt for klinisk medisin

Universitetet i Tromsø

\section{Thomas Berg}

Klinisk patologi

Universitetssykehuset Nord-Norge

\section{Bjørn Henning Grønberg}

Kreftklinikken

St. Olavs hospital

og

Institutt for kreftforskning og molekylær medisin Norges teknisk-naturvitenskapelige universitet

\section{Hong Yan Dai}

Sissel Gyrid Freim Wahl

Avdeling for patologi

St. Olavs hospital

\section{Kjersti Mangseth}

Lars Helgeland

Avdeling for patologi

Haukeland universitetssykehus

Lungekreft rammer årlig over 2500 personer i Norge (1). Flere enn 2100 dør hvert år, hvilket gjør sykdommen til den vanligste årsaken til kreftrelaterte dødsfall. Ca. $80 \%$ har ikkesmåcellet lungekreft, og to av tre diagnostiseres i et stadium der kurativt rettet behandling ikke er mulig (2). Inntil nylig har aktuell behandling for disse vært palliativ strålebehandling eller cellegift, ev. i kombinasjon. Mest aktuell cellegiftbehandling har vært en kombinasjon av platinum og et såkalt tredje- generasjons kjemoterapeutikum. I Norge har karboplatin sammen med vinorelbin vært mest brukt. Median overlevelse med slik behandling er 7-12 måneder (3).

I 2004 kom de første rapportene om at noen pasienter med ikke-småcellet lungekreft kunne ha nytte av tyrosinkinasehemmerne (EGFR-TKI) gefitinib og erlotinib (4-6). Relativt få pasienter responderte på slik behandling, men til gjengjeld var effekten overbevisende hos responderne. Man fant til å begynne med en korrelasjon mellom demografiske data og effekt. Hos kvinner, ikke-røykere, pasienter med adenokarsinom og pasienter av sørøstasiatisk herkomst var det høyest sannsynlighet for effekt (7).

Behandlingseffekt av erlotinib og gefitinib ble også rapportert å være assosiert med overuttrykk av EGFR-proteinet kvantifisert ved immunhistokjemi, amplifikasjon av genet målt med fluorescens in-situ-hybridisering (FISH), samt med spesifikke mutasjoner i genet som koder for EGFR (8).

I løpet av de siste par årene har flere arbeider entydig konkludert med at tilstedeværelsen av spesifikke mutasjoner i EGFR-genet i ikke-småcellet lungekreft er forbundet med spesielt god effekt av erlotinib og gefitinib $(9,10)$. Tilsvarende ser man at pasienter uten slike mutasjoner i liten grad har nytte av disse medikamentene.

Tre sentrale randomiserte fase III-studier har vist en betydelig forlenget progresjonsfri overlevelse med tyrosinkinasehemmerbehandling sammenliknet med konvensjonell kjemoterapi ved påviste mutasjoner i EGFR-genet. Mok og medarbeidere sammenliknet gefitinib og konvensjonell kjemoterapi i en asiatisk populasjon, og fant at mutasjonspositive pasienter oppnådde en progresjonsfri overlevelse på 9,6 måne-

\section{Hovedbudskap}

- Ved testing av over 1000 norske lungekreftpasienter fant vi mutasjon i EGFR-genet hos ca. $12 \%$

- Tre ganger flere kvinner enn menn hadde mutasjonen

- En ikke ubetydelig andel pasienter med morfologisk plateepitelkarsinom hadde mutasjon i EGFR-genet

- Vi anbefaler at EGFR-mutasjonstesting blir gjort som ledd i rutinediagnostikk av alle pasienter med ikke-småcellet lungekreft 
der med gefitinib, mot 6,3 måneder med kjemoterapi $(p<0,0001)(9)$. Rosell og medarbeidere rapporterte nylig data fra en europeisk studie, hvor mutasjonspositive pasienter ble randomisert mellom erlotinib eller kjemoterapi. I denne studien var progresjonsfri overlevelse 9,7 måneder med erlotinib, mot 5,2 måneder med kjemoterapi $(\mathrm{p}<0,0001)(11)$. En tredje studie, gjort i Kina, viste en progresjonsfri overlevelse hos mutasjonspositive på 13,1 måneder med erlotinib mot 4,6 måneder med konvensjonell kjemoterapi (12).

Det er ikke sett noen forlengelse i totaloverlevelse hos mutasjonspositive pasienter som får tyrosinkinasehemmere som førstelinjebehandling sammenliknet med pasienter som får cellegift i første linje $(9,10,12)$. Årsaken kan være at de fleste pasienter som ble behandlet med cellegift forst, fikk tyrosinkinasehemmerbehandling ved progrediering, og vice versa, og at effekten på totaloverlevelse dermed oppheves. Det viktigste er at totaloverlevelsen hos pasienter med mutasjoner behandlet med EGFR-TKI varierte mellom 18 og 27 måneder i de tre studiene, noe som er betydelig lengre enn tidligere observert ved avansert ikke-småcellet lungekreft, uansett rekkefølge på behandling.

Det er beskrevet en rekke ulike aktiverende mutasjoner som påvirker responsen på tyrosinkinasehemmerne. Alle er lokalisert i fire eksoner; 18-21, som koder for den ATP-bindende delen av kinasen. Det er beskrevet noe varierende frekvens av de ulike mutasjonene, de to hyppigst forekommende er delesjoner i ekson 19 (ca. 44\%), og en punktmutasjon i ekson 21 (ca. $41 \%$ ) (13). Man har antatt at forekomsten av mutasjoner hos pasienter med morfologisk plateepitelkarsinom har vært svært lav, men det er nylig publisert data som viser en ikke ubetydelig mutasjonsfrekvens også i denne undertypen av lungekreft $(14,15)$.

I Norge er både erlotinib (Tarceva) og gefitinib (Iressa) på markedet. Begge preparatene kan skrives på blåresept og er godkjent for bruk ved lokalavansert eller metastatisk ikke-småcellet lungekreft. Erlotinib kan benyttes uavhengig av mutasjonsstatus etter minst ett cellegiftregime, og har godkjenning som førstelinjebehandling hos mutasjonspositive pasienter. Gefitinib er kun godkjent ved påvist EGFR-mutasjonspositivitet, og kan benyttes i alle linjer. Behandling med tyrosinkinasehemmere gir andre bivirkninger enn konvensjonell cellegift. Hudutslett og diaré er de vanligste, mens hematologiske bivirkninger forekommer svært sjelden (9). Både erlotinib og gefitinib tas som en tablett daglig.

Den gode effekten av behandling med disse tyrosinkinasehemmerne hos pasienter med mutasjon i EGFR-genet har resultert i et behov for å gjøre genetiske undersøkelser på tumorvev fra alle pasienter som diagnostiseres med ikke-småcellet lungekreft (16). Norsk Lunge Cancer Gruppe har dermed anbefalt slik testing rutinemessig i Norge (17).
I denne artikkelen gjør vi rede for prosessen som har ført frem til genanalyser som del av rutinediagnostikk, og resultatene etter testing av de første 1058 pasientene.

\section{Materiale og metode}

Pasienter diagnostisert med ikke-småcellet lungekreft er fra våren 2010 blitt testet for mutasjoner i EGFR-genet. Molekylærpatologiske laboratorier ved universitetssykehusene i Tromsø, Trondheim, Bergen og Oslo har deltatt $i$ testingen, og disse fire sentrene har mottatt prøver fra hele landet. Frem til senhøsten 2010 ble plateepitelkarsinomer ikke anbefalt testet, men deretter har anbefalingen vært å teste ikke-småcellet lungekreft uavhengig av histopatologisk undertype.

Ved Haukeland universitetssykehus ble et lite antall pasienter testet også i perioden 2004-10, men disse er ikke inkludert i denne gjennomgangen. Det samme gjelder data fra Stavanger universitetssjukehus, som startet med EGFR-mutasjonsanalyser våren 2011.

Informasjon om kjønn, histologi og analyseresultat er innhentet fra laboratorienes egne databaser, andre journalopplysninger er ikke innhentet. Tilsendte prøver som ble avvist ved de molekylærpatologiske avdelingene pga. for lite tumorcelleinnhold, er ikke inkludert i materialet. Khikvadrattest er benyttet for sammenlikning av grupper.

Prosjektet er tilrådd av Personvernombudet ved Oslo universitetssykehus.

\section{Analysene}

Ved alle laboratorier analyseres de fire aktuelle eksonene; 18-21. I Bergen, Trondheim og Tromsø er basismetoden direkte sekvensering. I Trondheim og Tromsø gjøres i tillegg fragmentanalyse for spesifikke genforandringer (delesjoner i ekson 19, insersjoner i ekson 20 og punktmutasjonen L858R i ekson 21). Ved molekylærpatologisk laboratorium i Oslo ble det den første tiden gjort en totrinns analyse, med denaturerende høy-ytelse væskekromatografi (dHPLC) som første screeningsteg. Prøver med aberrante kromatogram ble deretter analysert med sekvensering. Senere er denne metoden forlatt av kapasitetshensyn, og mutasjonsanalysen gjøres nå ved sanntids-PCR med bruk av et kommersielt analysesett (TheraScreen), som analyserer for 28 av de hyppigst forekommende genforandringene i eksonene 18-21. Ekson 19-negative prøver blir også i Oslo etteranalysert med fragmentanalyse.

Genanalysene gjøres på formalinfiksert parafininnstøpt biopsimateriale, eller på cytologisk prøvemateriale. Prøver som skal til EGFR-undersøkelse blir vurdert av patolog, som markerer relevant tumorområde på tilhørende snitt. Fra dette området blir vev skrapet av, og DNA ekstrahert. Videre steg avhenger av metode, enten sanntids-PCR eller sekvensering.

\section{Logistikk}

Det har vært et mål for Norsk Lunge Cancer Gruppe at alle pasienter med ikke-småcellet

\begin{tabular}{|c|c|c|}
\hline & $\begin{array}{l}\text { Antall } \\
\text { testede }\end{array}$ & $\begin{array}{l}\text { Mutasjonspositive } \\
\text { Antall (\%) }\end{array}$ \\
\hline \multicolumn{3}{|l|}{ Kjønn ${ }^{1}$} \\
\hline Menn & 559 & $35(6,3)$ \\
\hline Kvinner & 499 & $88(17,6)$ \\
\hline Totalt & 1058 & $123(11,6)$ \\
\hline
\end{tabular}

lungekreft skal kunne tilbys $E G F R$-mutasjonsanalyse. De fleste sykehus følger anbefalingen fra gruppen, og parafinblokk og originalsnitt (farget med hematoksylin og eosin) blir sendt direkte fra lokal patolog til mutasjonsanalyse som ledd i rutinediagnostikk, slik at ikke utredningen forsinkes unødig. Ved universitetsavdelingene vil ansvarlig patolog rutinemessig rekvirere $E G F R$-mutasjonsanalyse. Ved enkelte avdelinger blir fortsatt analysen kun utført på bakgrunn av klinikers rekvisisjon, og enkelte steder blir dermed remissen stemplet med «EGFR-mutasjonsanalyse ønskes utført ved diagnose ikke-småcellet lungekreft». Svar fra molekylærpatologisk laboratorium sendes til behandlende lungelege eller onkolog, med kopisvar til lokal patologiavdeling.

\section{Resultater}

Fra mai 2010 til mai 2011 er det gjort EGFRmutasjonsanalyser på 1058 pasienter med ikke-småcellet lungekreft. Dette svarer til ca. halvdelen av alle som fikk diagnosen ikkesmåcellet lungekreft $\mathrm{i}$ denne perioden. Flest analyser er gjort i Oslo, med 470 pasientprøver, mens Bergen har testet 277, St. Olavs hospital 191 og Tromsø 120 pasienter. 559 menn og 499 kvinner ble testet (tab 1).

Totalt ble 123 pasienter funnet positive, altså 11,6\% av alle testede pasienter (fig 1). Vi fant mutasjoner hos fire av 135 pasienter med morfologisk plateepitelkarsinom (3,0\%), mens frekvensen hos pasienter uten plateepitelkarsinom var 119 av 923 (12,9\%) ( $p=0,001$ ) (fig1). 17,6\% av de testede kvinnene hadde mutasjon i kreftsvulsten mot $6,3 \%$ hos menn $(\mathrm{p}<0,001)$. Andelen positive varierte fra 7,5\% i Tromsø til 14,1\% ved St. Olavs hospital, men forskjellene var ikke statistisk signifikante. Alle sentrene rapporterer om økende antall analyseforespørsler. Vi har ikke oversikt over antall lungekreftpasienter som ikke er testet, men registrerer at antallet testede per måned har gått gradvis opp i løpet av dette første året og at andelen mutasjonspositive samtidig har gått gradvis ned (data ikke vist).

De fleste analysene var gjort på biopsier og operasjonspreparat, men $80(7,6 \%)$ var gjort på cytologiske prøver. Blant disse var $9(11,3 \%)$ positive. En liten andel $(<10 \%)$ av tilsendte prøver blir avvist ved de mole- 
kylærpatologiske avdelingene pga. for lite tumorcelleinnhold. Disse ikke-analyserte prøvene er ikke med i vårt materiale.

Mutasjonsvariantene var hovedsakelig delesjoner i ekson 19 (45\%) og punktmutasjoner i ekson 21 (34\%), mens forandringer i ekson 18 og 20 sto for henholdsvis $10 \%$ og $11 \%$ av mutasjonene.

\section{Diskusjon}

Vi rapporterer her resultatene fra det første året med rutinemessig analyse av mutasjoner i genet som koder for epidermal vekstfaktorreseptor hos pasienter med ikke-småcellet lungekreft. Totalt ble 1058 pasienter testet, og vi fant en mutasjonsrate på $11,6 \%$. Mutasjonsfrekvensen var om lag tre ganger hyppigere hos kvinner enn hos menn, og vi fant $3 \%$ mutasjonspositive plateepitelkarsinomer.

Norsk Lunge Cancer Gruppe etablerte i 2007 en translasjonsgruppe som skulle ha som formål å jobbe med ulike translasjonspregede prosjekter knyttet opp mot den kliniske lungekreftaktiviteten ved norske sykehus. Etter at IPASS-studien høsten 2009 avklarte at EGFR-mutasjon er hovedårsak til effekt av gefitinib (9), har denne gruppen arbeidet med å få innført $E G F R$-mutasjonstesting på et nasjonalt nivå.

EGFR-mutasjoner har fra tidligere vært kjent å være hyppigst forekommende hos kvinner, ikke-røykere og ved adenokarsinomer. Ifølge Kreftregisterets tall blir ca. 2600 årlig diagnostisert med lungekreft, hvorav $83 \%$ er ikke-småcellet lungekreft $(1,2)$. I vårt materiale er ca. halvdelen av de ca. 2100 nydiagnostiserte ikke-småcellete lungekrefttilfellene testet. Man kan anta at dette utvalget ikke nødvendigvis er representativt for hele lungekreftpopulasjonen, idet det trolig har vært en tendens til ikke å teste for eksempel storrøykende pasienter med plateepitelkarsinomer. Dette understøttes av vårt funn av at andelen positive har gått ned gjennom perio-

\section{Andel mutasjonspositive (\%)}

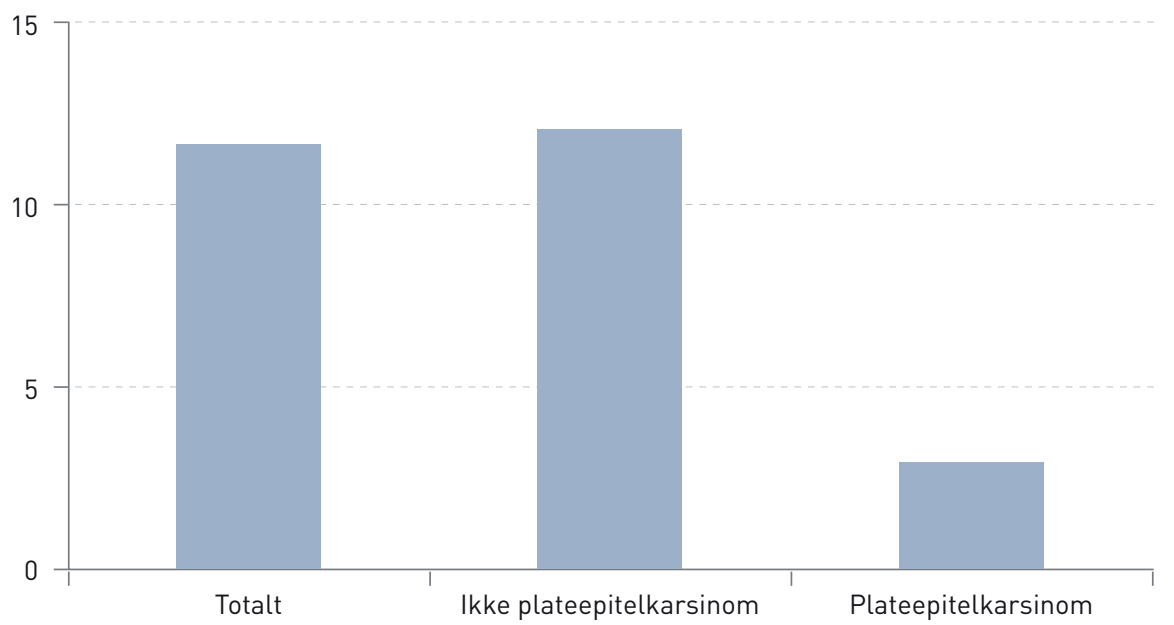

Mutasjonspositive

Figur 1 Prøveresultater fra 1058 pasienter med lungekreft som ble testet for mutasjoner i EGFR-genet i perioden mai 2010 til mai 2011 etter histopatologisk undertype den, etter hvert som en større andel av alle ikke-småcellete lungekarsinomer er blitt testet. Vi ser også en viss, men ikke-signifikant variasjon i mutasjonsfrekvens mellom laboratoriene. Dette kan reflektere en reell forskjell i mutasjonshyppighet, men kan like gjerne være en effekt av ulik grad av komplett testpraksis i de ulike regionene.

Kjønnsfordelingen blant de testede reflekterer det man ser i den generelle lungekreftpopulasjonen, hvor nå nesten like mange kvinner som menn får diagnosen.

I startfasen ble det ikke anbefalt å teste pasienter med plateepitelkarsinom, da man antok at mutasjonsfrekvensen hos denne pasientgruppen var svært lav. Ved Oslo universitetssykehus analyserte vi nylig en kohort av 240 uselekterte, opererte lungekreftpasienter, og fant en mutasjonsrate hos 60 pasienter med plateepitelkarsinom på $3 \%$, mens ca. 7,5\% av totalgruppen hadde mutasjon (14). Tilsvarende er også rapportert fra andre grupper (15). På bakgrunn av denne relativt lille forskjellen mellom de histologiske undergruppene fant Norsk Lunge Cancer Gruppe fra høsten 2010 å ville anbefale mutasjonstesting også ved plateepitelkarsinom som ledd i rutinediagnostikk. Foreløpig er kun 135 pasienter med plateepitelkarsinom analysert, og vi finner samme andel mutasjonspositive som i den uselekterte gruppen av tidligstadium lungekreft. Diagnostisering av histologisk undertype kan være usikker (18), noe som også er et argument mot å bruke vanlig histopatologisk undersøkelse som testkriterium. Vi ønsker derfor å gå videre med en mest mulig bred testepraksis, og evaluere dette på nytt om ett år.

Kjønnsfordelingen tilsvarer det man ser internasjonalt. Den høye andelen mutasjonspositive kvinner er tradisjonelt forklart med en fortsatt noe høyere andel ikke-røykere blant kvinnelige lungekreftpasienter. Om dette er hele sannheten, eller om andre kjønnsbetingede faktorer også spiller en rolle er uvisst (19).

Metodene for mutasjonsanalyse er primært etablert for undersøkelse av histologisk prøvemateriale, men cytologiske materialer kan benyttes. I materialet vi her har gått gjennom, er en større andel cytologiske enn histologiske prøver forkastet pga. for lite tumorvev (data ikke vist). En analyse gjort på en vevsprøve med lavt tumorcelleinnhold vil være mulig falskt negativ (20). Dette vil være kommentert av patolog, og i slike tilfeller bør rebiopsering vurderes.

Direkte sekvensering har vært ansett som «gullstandard», fordi man med dette vil kunne påvise både kjente og nye mutasjoner. Metoden har imidlertid noe lavere sensitivitet enn kommersielle analysesett og dHPLC. Ved de sistnevnte metodene er dermed tumorcelleandel i prøven mindre kritisk. De aller fleste mutasjoner er nå kjent og vil kunne påvises med forbedrede kommersielle tester som etter hvert kommer på markedet.

Innføring av mutasjonstesting som ledd $\mathrm{i}$ rutinediagnostikk av en vanlig kreftform som lungekreft stiller nye krav til logistikken ved de molekylærpatologiske laboratoriene. Svartiden varierer noe mellom de molekylærpatologiske laboratoriene, og har tidvis vært 3-4 uker fra registrert mottak av prøvemateriale. Vi erfarer nå en svartid på ca. 7-10 virkedager. Dette er innenfor det som nylig ble anbefalt av en europeisk ekspertgruppe (20). Vi ser at testfrekvensen øker, som følge av at det har tatt noe tid å få informert alle som diagnostiserer lungekreft om denne nye praksisen. Kapasiteten synes å tilfredsstille ønsket om å gjøre denne analysen tilgjengelig for alle pasienter med ikke-småcellet lungekreft i Norge. Stavanger universitetssjukehus har nylig startet EGFR-mutasjonstesting, og også Akershus universitetssykehus vurderer oppstart. Dermed vil behovet trolig bli dekket også fremover.

Vi har ikke hatt tilgang til behandlingsdata, og har dermed ikke hatt mulighet til å evaluere i hvor stor grad pasientene er blitt behandlet med tyrosinkinasehemmere. Vi kan følgelig heller ikke presentere terapirespons av slik behandling i denne artikkelen. Det arbeides med å opprette et nasjonalt kvalitetsregister for lungekreftbehandling. I dette vil også effektdata av EGFR-TKI-behandling registreres.

Molekylærpatologisk testing, i tillegg til økende behov for immunhistokjemisk analyse for sikrere histologisk subklassifisering, fordrer bedre tilgang på vev enn det som tradisjonelt har vært tilgjengelig etter bronkoskopisk diagnostikk av svulster i lunge. Flere molekylærgenetiske analyser vil trolig bli aktuelle i nær fremtid. Blant annet er det på tilsvarende måte som for $E G F R$-mutasjoner nå utviklet småmolekylære hemmere som er virksomme ved $E M L 4-A L K$-translokasjoner hos pasienter med ikke-småcellet lungekreft (19). Det pågår også kliniske studier av medikamenter som har effekt mot andre genforandringer i undergrupper av ikke-småcellet 
lungekreft. Vi anbefaler derfor at det tas rikelig med histologiske prøver. Dette sikrer at vev er tilgjengelig både til vanlig lysmikroskopisk undersøkelse og til immunhistokjemiske og molekylærpatologiske analyser.

\section{Konklusjon}

Av over 1000 testede lungekreftpasienter Norge fant vi EGFR-mutasjoner hos 11,6\%. Hos pasienter med plateepitelkarsinom var mutasjonsfrekvensen $3 \%$. På denne bakgrunn anbefaler vi fortsatt testing av alle pasienter med påvist ikke-småcellet lungekreft uavhengig av histopatologisk undertype.

Odd Terje Brustugun (f. 1970) er dr.med., spesialist i onkologi. Han er Fagansvarlig overlege for lungekreft ved Avdeling for kreftbehandling ved Oslo universitetssykehus og førsteamanuensis ved Universitetet i Oslo. Fra 1.1. 2012 er han leder av Norsk Lunge Cancer Gruppe. Forfatter har fylt ut ICMJE-skjemaet og oppgir følgende interessekonflikter: Han har mottatt forskningsstøtte, foredragshonorar og reisestøtte fra AstraZeneca og Roche.

Åslaug Helland (f. 1966) er spesialist i onkologi. Hun er overlege ved Oslo universitetssykehus, Radiumhospitalet, leder forskningsgruppe for lungekreftforskning og er førsteamanuensis ved Universitetet i Oslo. Fra 1.1. 2012 er hun leder av translasjonsgruppen i Norsk Lunge Cancer Gruppe.

Forfatter har fylt ut ICMJE-skjemaet og oppgir følgende interessekonflikter: Hun har mottatt forskningsstøtte, foredragshonorar og reisestøtte fra AstraZeneca og Roche.

Lars Fjellbirkeland (f. 1960) er overlege i lungemedisin ved Lungeavdelingen, Oslo universitetssykehus, Rikshsopitalet og førsteamanuensis dr.med. ved Klinisk institutt, Det medisinske fakultet, Universitetet i Oslo. Han er medlem av styret for Norsk Lunge Cancer Gruppe.

Forfatter har fylt ut ICMJE-skjemaet og oppgir følgende interessekonflikter: Han har mottatt foredragshonorar og reisestøtte fra Roche.

Lilach Kleinberg (f. 1971) er ph.d., overigeniører ved Laboratorium for molekylærpatologi, Avdeling for patologi, Oslo universitetssykehus. Forfatter har fylt ut ICMJE-skjemaet og oppgir følgende interessekonflikter: Hun har mottatt reisestøtte fra AstraZeneca og honorar fra Pfizer.

Sarah Ariansen (f. 1967) er Bachelor of Science i mikrobiologi og avdelingsingeniør ved Laboratorium for molekylærpatologi, Avdeling for patologi, Oslo universitetssykehus. Forfatter har fylt ut ICMJE-skjemaet og oppgir ingen interessekonflikter.

Peter Jebsen (f. 1955) er spesialist i patologi og overlege ved Oslo universitetssykehus, Rikshospitalet. Han er medlem av Norsk Lunge Cancer Gruppe.

Forfatter har fylt ut ICMJE-skjemaet og oppgir følgende interessekonflikter: Han har mottatt reisestøtte til konferanse fra AstraZenica og Pfizer.
Helge Scott (f.1949) er overlege og professor i patologi ved Oslo universitetssykehus, Rikshospitalet. Han har subspesialisering innen hjerte-, lunge- og nyrepatologi med bl.a. ansvar for lungekreftdiagnostikk.

Forfatter har fylt ut ICMJE-skjemaet og oppgir følgende interessekonflikter: Han har mottatt reisestøtte fra AstraZeneca.

Tom Dønnem (f.1970) er spesialist i onkologi, postdok ved Universitetssykehuset Nord-Norge/ Universitetet i Troms $\varnothing$, overlege ved Kreftavdelingen, Universitetssykehuset Nord-Norge og medlem av Translasjonsgruppen Norsk Lunge Cancer Gruppe.

Forfatter har fylt ut ICMJE-skjemaet og oppgir ingen interessekonflikter.

Roy M. Bremnes (f. 1957) er spesialist og professor i onkologi, Universitetssykehuset NordNorge/Universitetet i Troms $\varnothing$ samt leder for Translasjonell Kreftforskningsgruppe, Universitetet i Troms $\varnothing$. Han er medlem av styret for Norsk Lunge Cancer Gruppe.

Forfatter har fylt ut ICMJE-skjemaet og oppgir ingen interessekonflikter.

Thomas Berg (f. 1969) er dr. scient, , forsker ved Klinisk patologi, Universitetssykehuset Nord Norge og seniorrådgiver rettsgenetikk ved Universitetet i Troms $\varnothing$

Forfatter har fylt ut ICMJE-skjemaet og oppgir ingen interessekonflikter.

Bjørn Henning Grønberg (f. 1968) er spesialist i onkologi med lungekreft som hovedarbeidsfelt. Han er overlege, forsker og Avdelingssjef for forskning ved Kreftklinikken, St. Olavs hospital og medlem av styret i Norsk Lunge Cancer Gruppe.

Forfatter har fylt ut ICMJE-skjemaet og oppgir følgende interessekonflikter: Han har mottatt foredragshonorar og reisestøtte fra AstraZeneca og Roche.

Hong Yan Dai (f. 1962) er ph.d. i molekylærbiologi og overingeniør ved Seksjon for molekylær patologi ved Avdeling for patologi og medisinsk genetikk ved St. Olavs hospital.

Forfatter har fylt ut ICMJE-skjemaet og oppgir ingen interessekonflikter.

Sissel Gyrid Freim Wahl (f. 1967) er spesialist i patologi og overlege ved Avdeling for patologi og medisinsk genetikk, St. Olavs hospital. Forfatter har fylt ut ICMJE-skjemaet og oppgir følgende interessekonflikter: Hun har mottatt reisestøtte fra AstraZeneca og honorar fra Pfizer.

Kjersti Mangseth (f. 1977) er Master of Science (biomedisin/molekylærbiologi), avdelingsingeniør ved Avdeling for patologi, Haukeland universitetssykehus.

Forfatter har fylt ut ICMJE-skjemaet og oppgir ingen interessekonflikter.

Lars Helgeland (f. 1964) er dr.med., spesialist i patologi og overlege ved Avdeling for patologi, Haukeland universitetssykehus.
Forfatter har fylt ut ICMJE-skjemaet og oppgir følgende interessekonflikter: Han har mottatt foredragshonorar og reisestøtte fra AstraZeneca og honorar fra Pfizer.

\section{Litteratur}

1. Cancer in Norway. 2009. Oslo: Kreftregisteret, 2011. www.kreftregisteret.no/no/Generelt/ Publikasjoner/Cancer-in-Norway/Cancerin-Norway-2009/ (21.3.2012).

2. Sagerup CM, Småstuen M, Johannesen TB et al. Sex-specific trends in lung cancer incidence and survival: a population study of 40,118 cases. Thorax 2011; 66: $301-7$.

3. Helbekkmo N, Sundstrøm SH, Aasebø U et al. Vinorelbine/carboplatin vs gemcitabine/carboplatin in advanced NSCLC shows similar efficacy, but different impact of toxicity. Br J Cancer 2007; 97: 283-9.

4. Lynch TJ, Bell DW, Sordella R et al. Activating mutations in the epidermal growth factor receptor underlying responsiveness of non-small-cell lung cancer to gefitinib. N Engl J Med 2004; 350: 2129-39.

5. Pao W, Miller V, Zakowski M et al. EGF receptor gene mutations are common in lung cancers from «never smokers» and are associated with sensitivity of tumors to gefitinib and erlotinib. Proc Natl Acad Sci U S A 2004; 101: 13306-11.

6. Paez JG, Jänne PA, Lee JC et al. EGFR mutations in lung cancer: correlation with clinical response to gefitinib therapy. Science 2004: 304: 1497-500.

7. Tsao MS, Sakurada A, Cutz JC et al. Erlotinib in lung cancer - molecular and clinical predictors of outcome. N Engl J Med 2005; 353: 133-44.

8. Gazdar AF. Personalized medicine and inhibition of EGFR signaling in lung cancer. N Engl J Med 2009; 361: 1018-20.

9. Mok TS, Wu YL, Thongprasert S et al. Gefitinib or carboplatin-paclitaxel in pulmonary adenocarcinoma. N Engl J Med 2009; 361: 947-57.

10. Maemondo M, Inoue A, Kobayashi Ket al. Gefitinib or chemotherapy for non-small-cell lung cancer with mutated EGFR. N Engl J Med 2010; 362: 2380-8.

11. Rosell R, Carcereny E, Gervais R et al.. Erlotinib versus standard chemotherapy as first-line treatment for European patients with advanced EGFR mutation-positive non-small-cell lung cancer (EURTAC): a multicentre, open-label, randomised phase 3 trial. Lancet Oncol 2012; 13: 239-46.

12. Zhou $C$, Wu YL, Chen $G$ et al. Erlotinib versus chemotherapy as first-line treatment for patients with advanced EGFR mutation-positive non-smallcell lung cancer (OPTIMAL, CTONG-0802): a multicentre, open-label, randomised, phase 3 study. Lancet Oncol 2011; 12: 735-42.

13. Sharma SV, Bell DW, Settleman J et al. Epidermal growth factor receptor mutations in lung cancer. Nat Rev Cancer 2007; 7: 169-81.

14. Helland $\AA$, Skaug HM, Kleinberg L et al. EGFR gene alterations in a Norwegian cohort of lung cancer patients selected for surgery. J Thorac Oncol 2011; 6: 947-50.

15. Miyamae Y, Shimizu K, Hirato J et al. Significance of epidermal growth factor receptor gene mutations in squamous cell lung carcinoma. Oncol Rep 2011; 25: $921-8$.

16. Rosell R, Moran T, Queralt C et al. Screening for epidermal growth factor receptor mutations in lung cancer. N Engl J Med 2009; 361: 958-67.

17. Den norske patologforening. EGFR - ny anbefaling om rutine ved all ikke-småcellet lungekreft. www.legeforeningen.no/id/167991.0 (5.2.2012).

18. Edwards SL, Roberts C, McKean ME et al. Preoperative histological classification of primary lung cancer: accuracy of diagnosis and use of the nonsmall cell category. J Clin Pathol 2000; 53: 537-40.

19. Planchard D, Loriot Y, Goubar A et al. Differential expression of biomarkers in men and women. Semin Oncol 2009; 36: 553-65

20. Pirker R, Herth FJ, Kerr KM et al. Consensus for EGFR mutation testing in non-small cell lung cancer: results from a European workshop. J Thorac Oncol 2010; 5: 1706-13.

Mottatt 6.9. 2011, første revisjon innsendt 12.1. 2012, godkjent 2.2. 2012. Medisinsk redaktør Siri Lunde. 